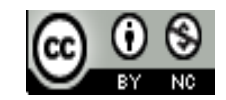

Jurnal Pendidikan Matematika Indonesia is licensed under A Creative Commons Attribution-Non Commercial 4.0 International License.

\title{
College Student's ERror AnAlysis BASEd ON THEIR MATHEMATiCAL CONNECTIONS ON GRAPH REPRESENTATION
}

\author{
I Ketut Suastika $^{1)}$, Vivi Suwanti ${ }^{2)}$ \\ ${ }^{1,2)}$ Universitas Kanjuruhan Malang,Malang, Indonesia \\ E-mail: suastika@unikama.ac.i ${ }^{1)}$, vivi_devbatghost@unikama.ac.id ${ }^{2)}$
}

\begin{abstract}
This study is investigates the college student's errors on their graph representations making based on the mathematical connections indicators. Pilot studies were conducted with 4 college students of middle to high ability in Graph Theory class. Data analyze revealed that top 3 subject's errors are 1) Finding the relations of a representations to it's concepts and procedures, 2) Applying mathematics in other sciences or real life problems, and 3) Finding relations among procedures of the equivalent representations. Their lack of graph concepts understanding and it's connections plays the major role in their errors. They failed at recognizing and choosing the suitable properties of graph which able to detect the error of their graph representation. So, in order to decrease college student errors in graph representations, we need to strengthen their basic concepts and its connections.
\end{abstract}

Keywords: error, mathematical connectios, graph, representation

\section{INTRODUCTION}

Graph theory is one of mathematical discipline that unseparated from representation making process. Graph itself, especially unlabeled graph, has five representations that have to introduced in the class. They are in form of sets and list (especially for labeled graph), degree sequence (especially for unlabeled graph), graphic of vertexs and edges, adjacent matrix, and incident matrix. Each representation forms of a graph have their own functions in learning process of graph theory and it's application (Suwanti, 2016).

When make a representation, students have to: (1) understand the procedure, (2) understand which part of the concept that they represented, (3) connect one representation to anothers to know that they are equivalent, and (4) translate a representation to their other forms (Wong, Yin, Yang, \& Cheng, 2011). In other words, students used a lot of their mathematical connection ability involved at process of making a representation. The similar things also occurs to college students when making a graph representations. Rahmawati (2017) said that, translation proses of a representation to their equivalent forms can be done in four stages, they are (1) unpacking the source, (2) preliminary coordination, (3) constructing the target, and (4) determining equivalence. In more complex representations, this stages would be done in one or more translation process through the intermediary representation. A study also pointed out that, students encounter difficulties in making process of graph multi representations, especially on translation of an adjacent matrix to incident matrix and vice versa, because they need the graphic representation as the intermediary to translate from one representation to another (Suwanti, 2016). Some study pointed out that, student's erorr mostly occurred because they are only memorize the mathematical concepts or procedures without understand them (Rohma \& Sutiarso, 2018; Farida, 2015; Andriani, Suastika, \& Sesanti, 2017; Murniasih \& Suwanti, 2017). In other words, student's errors in solving mathematics problems emerge because of their lack in understanding the concepts/ procedures of mathematics and their connections. It shows that conceptual and procedural understanding are not the only important factors that caused the students errors, but mathematical connections is also important.

Mathematical connections is an ability to connect mathematics concepts and idea to another concept of both internally in mathematics or other sciences and real life problems (Malasari, Nindiasari, \& Jaenudin, 2017). There are two general types of mathematics connections, they are modeling connections and mathematical connections. Modeling connections is a relation between real life problem or another discipline topics with their mathematics representation. Mathematical connections is a relation of two or more equivalent representations and their procedures (Sapti, 2010). Sumarmo and Nishitani formulated indicators of mathematical connections ability as : (1) finding the 
relations of a representations to it's concepts and procedures, (2) understanding the relations among mathematics topics, (3) applying mathematics in other sciences or real life problems, (4) understanding the equivalent representations of a concept, (5) finding relations among procedures of the eqivalent representations, (6) applying the relations among topics in mathematics or between mathematical topics with other topics outside mathematics (Dewi \& Kusuma, 2014). From all the previous descriptions, we can say that student's mathematical connections and representations ability are related to each other.

Acctually, the errors in student's mathematical representations has been researched by some researcher like Tasman, Yenti, \& Heriyanti (2016), who analyze transformation error in mathematics representations, and Suryowati (2015), who research about student errors ini fractions representation. However, in this study we would like to focus in analyze the college student's error in representation based on mathematical connection indicators. It because the error in representation making, like graph representations, could have been emerge because of their mathematical connections ablity. So, this study aim is to investigate the college student's errors on their graph representations based on the mathematical connections indicators.

\section{METHODS}

This study employs qulitative research methods. Subjects of the study are 4 mathematics education college students with middle to high ability in graph theory class. The selection of subject are done by test and observation while graph theory class take a place. This study would be carried out by (1) prior observation, (2) representation test, (3) interview, and (4) data analysis.

Prior observation was done to know what problems that occur in instruction process. From informations in observation, the research instruments was constructed to select the research subjects. The test sheet consist of 5 questions about graph representation. The questions was made based on mathematical connections indicators of by Sumarmo and Nishitani (Dewi \& Kusuma, 2014). The subject was chosen by their score in the test. 4 out of 30 college students who take the test was chosen as the subject of this study. 2 of them has average score and the others has high score. The chosen subjects would be interviewed to deeply analyze their errors and mathematical connections. Data from observation, test, and interview would be analyze by qualitative data analyze steps, they are (1) data reductions, (2) data displays, and (3) conclusions.

\section{RESULTS AND DISCUSSION}

Based on the purpose of the study, the test sheet was constructed in term of mathematical connections indicators. Mathematical connections indicators tha emerge in every questions could be seen in table I.
TABLE I

TEST SheEt CONTENTS BASED ON MATHEMATICAL INDiCATORS

\begin{tabular}{|c|c|c|c|c|c|}
\hline \multirow{2}{*}{$\begin{array}{l}\text { Mathematical connections } \\
\text { indicators that emerge (MC) }\end{array}$} & \multicolumn{5}{|c|}{ Question number } \\
\hline & $Q 1$ & $Q 2$ & Q3 & $Q 4$ & $Q 5$ \\
\hline $\begin{array}{l}\text { Finding the relations of a } \\
\text { representations to it's concepts and } \\
\text { procedures (MC1) }\end{array}$ & V & V & $\mathrm{V}$ & & \\
\hline $\begin{array}{l}\text { Understanding the relations among } \\
\text { mathematics topics (MC2) }\end{array}$ & & V & & V & \\
\hline $\begin{array}{l}\text { Applying mathematics in other } \\
\text { sciences or real life problems (MC3) }\end{array}$ & & & & & V \\
\hline $\begin{array}{l}\text { Understanding the equivalent } \\
\text { representations of a concept (MC4) }\end{array}$ & V & & & V & \\
\hline $\begin{array}{l}\text { Finding relations among procedures } \\
\text { of the equivalent representations } \\
\text { (MC5) }\end{array}$ & & & V & V & \\
\hline $\begin{array}{l}\text { Applying the relations among topics } \\
\text { in mathematics or between } \\
\text { mathematical topics with other topics } \\
\text { outside mathematics (MC6) }\end{array}$ & & & & & V \\
\hline
\end{tabular}

The mathematical connections ability of each subjects would be examines both from their answers and the reasoning behind. Firstly, we will examines the written errors in each subject's answers. Table 2 is displays their errors based on their answers in the test sheet.

TABLE II

ERRORS BASED ON THE ANSWERS IN TEST SHEET

\begin{tabular}{|c|c|c|c|c|c|}
\hline \multirow[b]{2}{*}{ Subjects } & \multicolumn{5}{|c|}{ Errors from the answer } \\
\hline & $\begin{array}{l}Q 1 \\
(M C 1, \\
M C 4, \\
M C 5)\end{array}$ & $\begin{array}{l}Q^{2} \\
(M C 1, \\
M C 2)\end{array}$ & $\begin{array}{l}Q 3 \\
(M C 1, \\
M C 5)\end{array}$ & $\begin{array}{l}Q 4 \\
(M C 4, \\
M C 5)\end{array}$ & $\begin{array}{l}Q 5 \\
(M C 3, \\
M C 6)\end{array}$ \\
\hline $\mathrm{RP}$ & $\mathrm{O}$ & $\mathrm{O}$ & $\mathrm{O}$ & $\mathrm{O}$ & $\mathrm{X}$ \\
\hline AA & $\mathrm{O}$ & $\mathrm{O}$ & $\mathrm{X}$ & $\mathrm{O}$ & $\mathrm{X}$ \\
\hline YP & $\mathrm{O}$ & $\mathrm{X}$ & $\mathrm{X}$ & $X$ & $\mathrm{O}$ \\
\hline $\mathrm{HO}$ & $\mathrm{O}$ & $\mathrm{O}$ & $\mathrm{X}$ & $\mathrm{O}$ & $\mathrm{X}$ \\
\hline
\end{tabular}

$X$ : error answer

$O$ : right answer

Table 2 shows that the most errors occurs at answer of question 3. Just as shown at table 1, question 3 (Q3) was purposely made to examine MC1 and MC5. The representations that involve in Q3 is incident matrix. The most errors also happen at question 5 (Q5). The subject's errors are happen when they translate the real life problem in their suitable mathematical model of graph (MC3). They are able to connect their graphic representation and cycle concept of graph to solve the route problems but never retranslate them to the real life solutions (MC6).

Secondly, each subjects will have a private interview about their answer in every test questions. In this steps, we are not only examine their error answers in the test sheet, but also seeking for the error concepts, procedures, and 


\section{일.}

Jurnal Pendidikan Matematika Indonesia

Volum 4 Nomor 1 bulan Maret 2019 Page 18 - 23

p-ISSN: 2477-5967 e-ISSN: 2477-8443 connections which are hiding behind the right answers. Errors are visible in subjects answers, however missconceptions are often hidind behind a correct answers (Luneta \& Makonye, 2010). So, we need to dig deeper their reasoning when work to solve the problems.

\section{Question $1(Q 1)$}

Q1 involves 2 graph representations, they are degree sequence and graphic. It was made to emerge MC1 (finding the relations of graphic and degree sequence representation to it's concepts) and MC4 (understanding the equivalent of graph representation in graphic dan degree sequence). Q1 was formed in true false question. As shown in table 1, all of subjects has no error in anwesring Q1. But, as we ask their reasoning behind the answer, $\mathrm{RP}$ was failed at $\mathrm{MC} 1 \mathrm{He}$ failed at finding the relations of a graphic representation of a vertex that contain a loop to it's degree concepts. The same thing also happen with $\mathrm{HO}$.

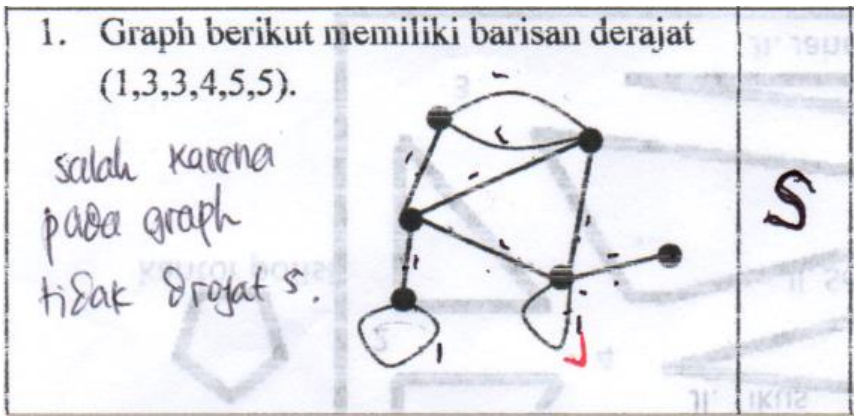

Fig 1. RP's answer for Q1 with error in MC1

\section{Question $2(\mathrm{Q} 2)$}

Just as Q1, Q2 also in form of true false question. Q2 was purposely made to examine $\mathrm{MC} 1$ (finding the relation of degree sequence representation to its concepts) and MC2 (understanding the relation among degree sequence representation and simple graph concepts). Two out of four subjects was made an error in Q2. Firstly YP, he failed both at MC1 and MC2. YP failed to connect between simple graph concepts and degree sequence as graph representation. As shown in fig. 2, YP assume that only simple graph that have even result in their sum of degree. But in fact, this properti is valid for all kind of graph. It also shows that YP failed to connect degree sequence as graph representation with it's concepts.

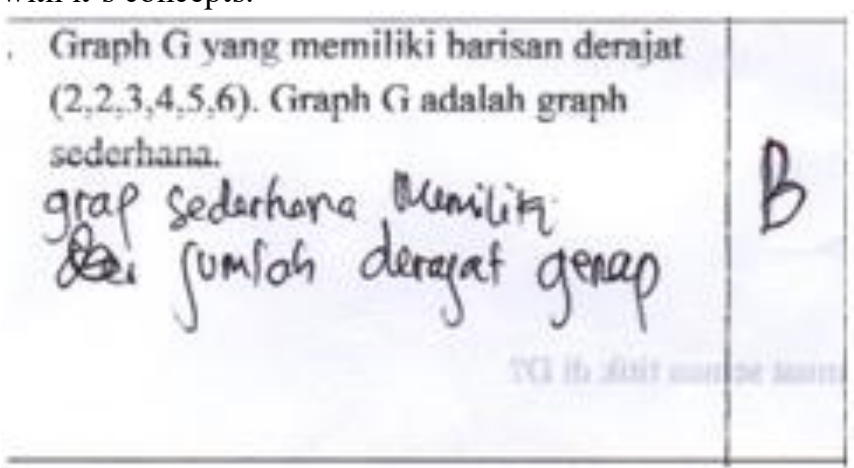

Fig 2. YP's answer for Q2 with error in $\mathrm{MC} 1$ and $\mathrm{MC} 2$
Secondly $\mathrm{HO}$, his answer was right but there is an error in his reasoning on answer. He had an error at MC2, because failed to identify the relation of maximum vertex degree in simple graph and complete graph's properties.

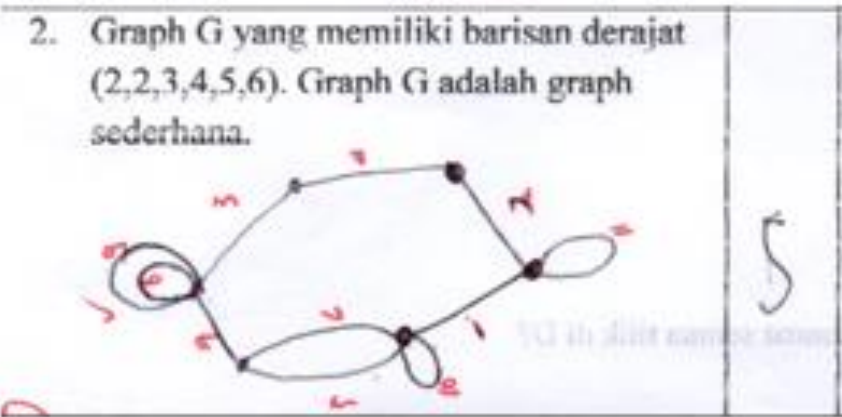

Fig 3. HO's answer for Q2 with error in $\mathrm{MC} 2$

Question 3 (Q3)

At Q3, we involve incident matrix as the graph representation. Q3 was made to examine MC1 (finding the relations of incidence matrix representation to it's concepts) and MC5 (finding relations among prosedures of incidence matrix and graphic representation of graph). 3 out of 4 subjects have error in both their answer and reasoning behind it. Firstly AA, he has an error because assume that the number of column and row of incident matrix from three vertex graph was 3 . This error emerge because AA connect the incident matrix form only with simple graph where the maximum number of edges could be drawn in $\mathrm{n}$ vertex graph was equal to the number of edges of the complete graph with $\mathrm{n}$ vertex $\left(\mathrm{K}_{\mathrm{n}}\right)$. He wasn't consider about a possibility of multiple edges existence. So, AA get errors in MC1 and MC5

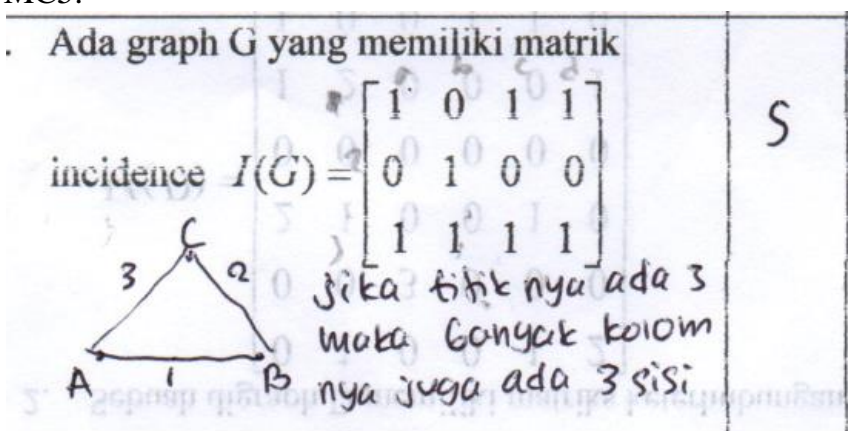

Fig 4. AA's answer for Q3 with error in MC1 and MC5

Secondly YP,he was correctly used the concept of incident matrix to make three labeled vertices and their labeled incident edges. After that he connect each incident edges with the same label. But YP assume that connect vertex 2 and 3 was wrong. He conclude that there is no corresponding graph with that kind of incident matrix. So YP has error in MC5. The last is $\mathrm{HO}$ who has no reasoning in his answer. So, HO has error in MC1 and MC5. 


\section{- - - Jurnal Pendidikan Matematika Indonesia \\ Volum 4 Nomor 1 bulan Maret 2019 Page 18 - 23 \\ p-ISSN: 2477-5967 e-ISSN: 2477-8443}

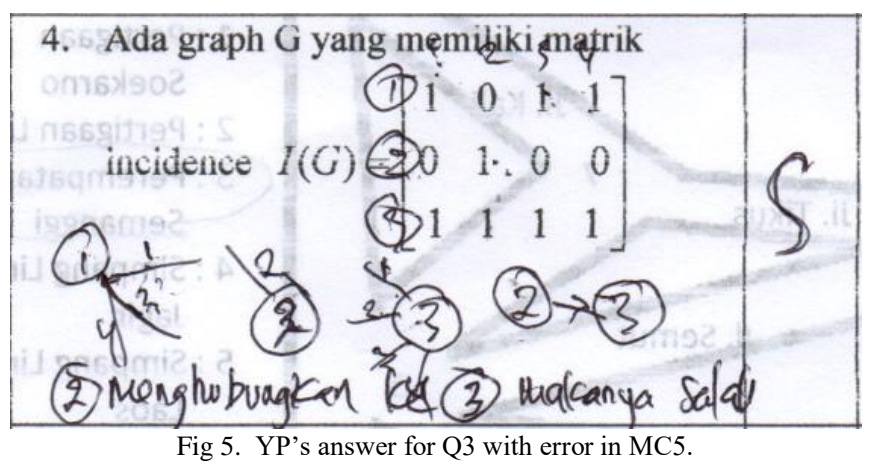

\section{Question 4 (Q4)}

Q4 was a question about translate a graphic representations of graph to adjacent and incident matrix. Q4 was made to emerge MC2 (understanding the relation among matriks and graph representation concepts), MC4 (understanding the equivalent of graphic, adjacent matrix, and incident matrix representation of graph), and MC5 (finding relations among procedures of graphic, adjacent matrix, and incident matrix representation of a graph). All subjects already use the rigth procedures to translate the representations. Although 2 out of 4 subjects didn't know how to relate the properties of adjacent and incident matrix (such as the sum of coloumn or row entries) to it's graphical representation. This causes the subjects couldn't recheck their own works (MC4). This error in finding the relation of equivalent representations was occur in YP and HO. As for $\mathrm{MC2}$, the slighty miss was done only in YP's work. He wrote the adjacent and incident matrix graph representation without bracket sign as the matrix formula. But he do understand that they are matrix.

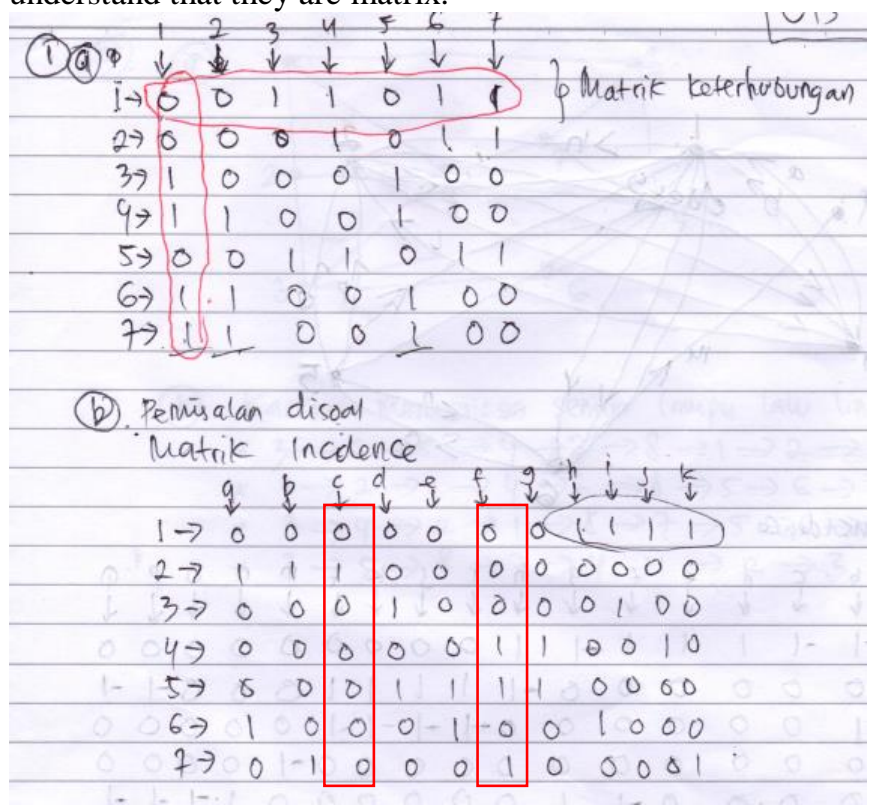

Fig 6. YP's answer for Q4 with error in MC2 and MC4

\section{Question 5 (Q5)}

Q5 was made to emerge MC3 (applying graphic representation of graph to models a real life problem) and MC6 (applying relation among graphic representation of graph and hamilton cycle to solve police route problem). RP, $\mathrm{AA}$, and $\mathrm{HO}$ was made wrong graph to model the real life problems (MC3).

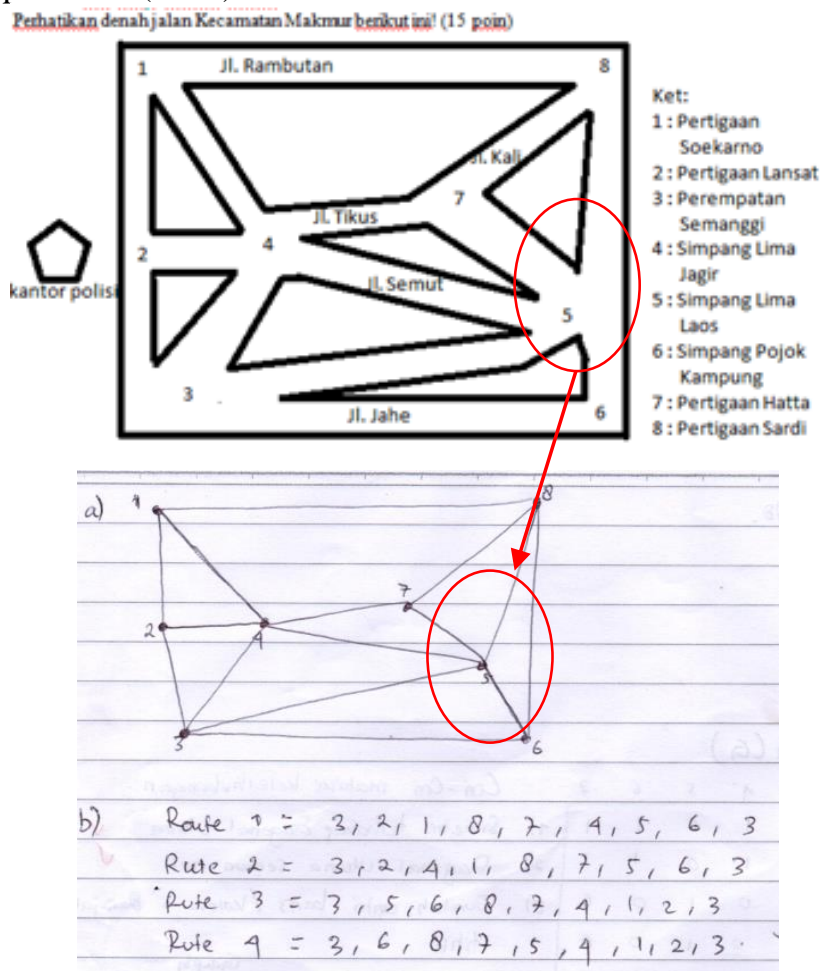

Fig 7. HO's answer for Q5 with error in MC3

$\mathrm{RP}$ and $\mathrm{HO}$ error was in point 5,6 , and 8 because they assume that to go from 6 to 8 , they didn't have to past the 5 . As for AA, she also error in point 5 because she don't connect 5 to 6 and 8 . This result in her error at finding 4 hamilton cycle to solve the route problems. RP, HO, and AA was knew to use hamilton cycle in graph to find the requested route, but they didn't retranslate their answer to real life solutions even though they do understand it.

Based on the result of interview, we can conclude them in the following table

TABLE III

SUBJECT'S ERROR BASED ON INTERVIEW

\begin{tabular}{cccccc}
\hline \multirow{2}{*}{ Subjects } & \multicolumn{5}{c}{ Errors from the interview } \\
\cline { 2 - 6 } & $\boldsymbol{Q 1}$ & $\boldsymbol{Q 2}$ & $\boldsymbol{Q 3}$ & $\mathbf{Q 4}$ & $\boldsymbol{Q 5}$ \\
\hline RP & MC1 & - & - & - & MC3 \\
AA & - & - & MC1, & - & MC3, \\
& & & MC5 & & MC6 \\
YP & - & MC1, & MC5 & MC4 & - \\
& & MC2 & & & \\
HO & MC1 & MC2 & MC1, & MC4 & MC3 \\
& & & MC5 & & \\
\end{tabular}

The subject error from table 3 can be shows in graphic as follows. 


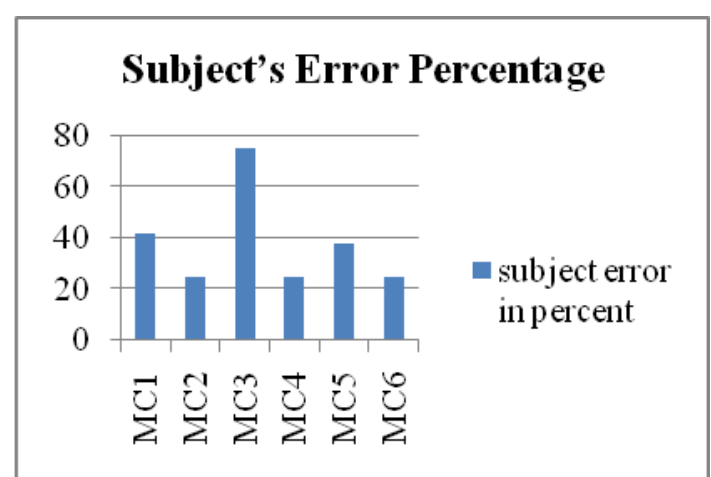

Fig 8. Subject's error based on test and interview

From the fig. 8 we can see the top 3 subject's errors are 1) Finding the relations of a representations to it's concepts and procedures (MC 1), 2) Applying mathematics in other sciences or real life problems (MC 3), and 3) Finding relations among procedures of the equivalent representations (MC 5).

\section{Finding the relations of a representations to it's concepts and procedures (MC 1)}

Almost all of this study subjects has an error in finding relation among graph representations and it's concepts. Even though their errors are in different graph representations. They failed at relate the graph representations and it's properties suchs as their vertex degree in grapichal representation and column/row count in matriks representation.

Graph theory is inseparable from multi representations making process. Understanding the equivalent representations of graph is also connected to the college students conceptual understanding. We can see that in table 3 where two subject with error in finding relation among representation and its concept also has an error in understanding the equivalent representations of a graph and finding relations among procedures of the eqivalent graph representations, especially among incident or adjacent matrix with graphic representations. They couldn't recheck their own work in translating one graph representation to the other forms because they didn't understand how to relate each properties of the representations. Just as Murniasih\&Suwanti (2017) said, some factor of colledge student errors are because their lack in concept understanding and finding the appropriate procedures to solve the problems. This will cause the college students inability to recheck the error in their works.

Relate a representation and it's concepts make an easier environment for college students to better understanding graph theory. The college students error in finding the relation of a representation to it's concepts and procedures, shows that their learning process in graph theory not enough to build and solidify their concept of graph in mind. As Suastika (2017) say, with strong grasp of concept in mind, students will be easily solve a problem by relate to it's right concepts.
Applying mathematics in other sciences or real life problems (MC 3)

Error in applying graph concept in other sciences or real life problems also occur in almost subjects. They fail in translate the real life problems to the suitable graph representations. They are too focused in the picture and less attention to the explanation. A study (Wijaya, Van den Heuvel-Panhuizen, Doorman, \& Robitzsch, 2014) also said that the most errors that students made when solving contextual-based problems are in comprehending and transforming stage. So, it is important to paying more attention in this two stages to improve colledge students performance in applying graph theory to solving real life problems.

\section{Finding relations among procedures of the equivalent representations (MC 5)}

Errors in finding relations among procedures of the equivalent graph representations, mostly occured when matrixs representation of graph involved. It shows from the incorrect steps that the colledge students take to transforms the matrix representation to the other one. Because to make a representation, they have to be able to connect one representation to anothers to know that they are equivalent, and translate them to their other forms (Wong, Yin, Yang, \& Cheng, 2011). This errors was worsened by their lack of ability to relate graph representations to their concepts. So they couldn't recheck the correctness of their equivalent representation.

\section{CONCLUSIONS}

Based on the data analysis can be conclude that : (1) college students errors in finding relations among representations and its concept would also affect error in other indicators of mathematical connections, (2) colledge students lack understanding in relate equivalent representations of graph would increase the chance of error because they couldn't recheck their own work, (3) college students error in applying graph concept to modeling real life problems are because they are too focused in graphical appearance without noticing the informations. Basic concepts of a graph plays a major role in graph representation making process. College students need to connect not only among graph concepts but also other science concepts. So, in order to decrease college student errors in graph representations, we need to strengthen their basic concepts and its connections. For the next study, we could develop a better instrument that examine the error in mathematical connections.

\section{ACKNOWLEDGMENT}

We would like to thank Mathematics Education Study Program Of Kanjuruhan University to provide this study subjects. 


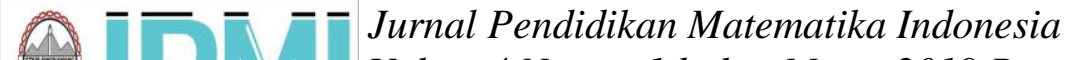 \\ Volum 4 Nomor 1 bulan Maret 2019 Page 18 - 23 \\ p-ISSN: 2477-5967 e-ISSN: 2477-8443}

\section{REFERENCES}

Andriani, T., Suastika, I. K., \& Sesanti, N. R. (2017). Analisis kesalahan konsep matematika siswa dalam menyelesaikan soal trigonometri kelas $\mathrm{X}$ TKJ SMKN 1 Gempol tahun pelajaran 2016/2017. Pi: Mathematics Education Journal, 1(1), 34-39.

Dewi, N. R. \& Kusumah, Y. S. (2014). Developing test of high order mathematical thinking ability in Integral Calculus subject. International Journal of Education and Research, 2(12), 101-108.

Farida, N. (2015). Analisis kesalahan siswa SMP kelas VIII dalam menyelesaikan masalah soal cerita matematika. Aksioma: Jurnal Pendidikan Matematika FKIP Universitas Muhammadiyah Metro, 4(2), 42-52.

Luneta, K. \& Makonye, P. J. (2010). Learner errors and misconceptions in elementary analysis: a case study of a grade 12 class in South Africa. Acta Didactica Napocensia, 3(3), 35-46.

Malasari, P. N., Nindiasari, H., \& Jaenudin. (2017). A development of mathematical connecting ability of students in junior high school through a problembased learning with course review Horay method. Journal of Physics: Conference Series 812, 1-6.

Murniasih, T. R. \& Suwanti, V. (2017). Analysis of college students error in solving basic mathematics problem with Newman. Proceeding $8^{\text {th }}$ ADRI 2017 International Conference and Call for Paper. 288292.

Rahmawati, D., Purwanto, Subanji, Hidayanto, E., \& Anwar, R. D. (2017). Process of Mathematical Representation Translation from Verbal into Graphic. International Electronic Journal of Mathematics Education, 12(3), 367-381

Rohma, M. \& Sutiarso, S. (2018). Analysis problem solving in mathematical using theory Newman. EURASIA Journal of Mathematics, Science, and Technology Education, 14(2), 671-681.

Sapti, M. (2010). Kemampuan koneksi matematis (tinjauan terhadap pendekatan pembelajaran SAVI). LimitPendidikan Matematika, (11), 60-69.

Suastika, I. K. (2017). Mathematics learninng syntax model using open-ended problem solving to develop students' creativity. Pancaran Pendidikan, 6(4), 105-112.

Suryowati, E. (2015). Keslahan Siswa Sekolah Dasar dalam Merepresentasikan Pecahan Pada Garis Bilangan. Aksioma : Jurnal Pendidikan Matematika FKIP Univ. Muhammadiyah Metro, 4(1), 38-52.

Suwanti, V. (2016). Kesulitan mahasiswa dalam pembuatan multi representasi graf. Prosiding Seminar Nasional Pendidikan Matematika Pascasarjana Universitas Negeri Malang. 1120-1128.

Tasman, F., Yenti, I. N., \& Heriyanti, S. (2016). Analisis kesalahan transformasi soal pada kemampuan representasi matematis secara simbolik. Eksakta, 2, 24-30.
Wijaya, A., Van den Heuvel-Panhuizen, M., Doorman, M., \& Robitzsch, A. (2014). Difficulties in solving context-based PISA mathematics task: an analysis of students' errors. The Mathematics Enthusiast, 11(3), 555-584.

Wong, W. K., Yin, S. K., Yang, H.H., \& Cheng, Y.H. (2011). Using Computer-Assisted Multiple Representations in Learning Geometry Proofs. Internatonal Forum of Educational Technology \& Society (IFETS), 14(3), $43-54$. 